\title{
Credit Risk Management Practices in Dashen Bank of Mettu Branch in Ethiopia
}

\author{
http://doi.org/10.21272/fmir.5(2).86-106.2021
}

\section{S.N. Singh}

Dr, Associate Professor of Economics and Law in the Department of Economics, Faculty of Business and Economics, Mettu University, Mettu, Ethiopia

\begin{abstract}
Credit Risk management becomes major discussion issues in the financial institutions because of uncertainty related to borrower's business. The aim of this study is to assess credit risk management tools and technique that are being used in the bank and to what extent the current performance of the bank is supported by proper credit risk management policy, procedure and strategy. The study design is descriptive. The research applies for both qualitative and quantitative research method and both primary data (questionnaire) and secondary data were collected to meet the objective of the study. 15 out of 20 total population Purposive samples were involved at Branch office using census sampling method who works on credit to get reliable and valid information about the study subject. The data was analyzed using qualitative and descriptive statistics technique and frequency table. From the findings the study concludes that the bank has well organized credit policy that counter to credit risk they are exposed to and it also conclude that the bank has good credit granting practice and uses suitable credit risk assessment tools and techniques including loan follow-up, risk identification, measuring, evaluating, monitoring and controlling mechanism. However, the study also concluded that the bank has pitfalls such as absence of training for customers which results to loan diversion, absence of credit risk model that predict the risk level of the business and the priority sectors of the bank in terms of credit facility are highly exposed to credit risk which directly contribute to the increment of NPL. Thus, it is recommended that Dashen Bank S.C should develop independent risk management policy and procedure from credit policy and procedure to overcome those problems and to take measure on the spot.
\end{abstract}

Key words: Credit Risk Management, Dashen Bank, NPL, Loan Diversion and Credit Process.

JEL Classification: G1, G20, G21.

Cite as: Singh, S.N. (2021). Credit Risk Management Practices in Dashen Bank of Mettu Branch in Ethiopia. Financial Markets, Institutions and Risks, 5(2), 86-106. http://doi.org/10.21272/fmir.5(2).86-106.2021

Received: 16 April, 2021

Accepted: 19 May, 2021

Published: 25 June, 2021

Copyright: (C) 2021 by the author. Licensee Sumy State University, Ukraine. This article is an open access article distributed under the terms and conditions of the Creative Commons Attribution (CC BY) license (https://creativecommons.org/licenses/by/4.0/)

\section{Introduction}

In the past revolution period, financial sector and institutions were nationalized and consolidated in to specialized Banks. At that period the country was followed the socialist economic system. Hence, all banks including National Bank of Ethiopia were thought to function as government to favor and promote to development and sustenance of the socialites sectors (cooperatives). In the world of competition, the survival of any organization is directly dependent on the strategy how the firm maximizes profit and minimizes cost. Effective and efficient use of resources in general and finance in particular in any organization is paramount important for the improvement of productivity of the organization, for the country's economic growth and development The effect of good loans and advances process has contributed a lot to the growth of bank loans and has an effect in expanding itself into the economy at large. Hence, a bank is concerned about the quality of its credit procedure and techniques. (Dashen Bank Training Material 2001, A.A). Banks are mainly concerned with accepting deposits for the purpose of lending or investment. In any country's economy, there will be people and institutions with surplus funds which they do not require for their immediate use and wish to place these surplus funds in an institution both for security and also to gain some income by way of interest. This institution would then lend the money to the ultimate borrowers at an interest rate higher than what they 
pay to their depositors.

The word credit is derived from the Latin word "creditum" which means believers or trust. In economics, "credit "refers to a promise by one party to pay another for money borrowed or goods or service received. Jhingan (2002).Another definition of credit is that it is originated from the Latin word " Credo " which means 'I believe'. Credit is a matter of faith in the person and no less than in the security offered. Credit is purchasing power not derived from income, but by financial institutions either as an offset to idle by depositors in the banks, or as net addition to the total amount of purchasing power. In fact, no economy can function without credit; all economic transactions are settled by means of credit linstruments today. It is the very life blood of modern business and commercial system. Cole (2000)

So Dashen Bank S.C is one of the private banks in Ethiopia playing an important role in country's economy and social life. Among the various services provided by the bank, lending has been the primary activity for a decade it advances large sum of money to borrowers. It is equally true that bank loans, as they are profitable, are equally risky. Bank loans fluctuate and are influenced by the changes in the economic policies and the economy in general. It is very important for the banks to formulate and update their loan polices in order to minimize risk associated with them.(Dashen Bank credit follow-up procedures, 2008). This research focuses on the credit management policy and practice. What are the polices implemented by the bank related to loans, how Dashen Bank measure its loan practice to minimize credit risk and what is the contribution of Dashen Bank in the growth of country's economy regardless of the loan.

\subsection{Background of the organization}

Dashen Bank S.C is a privately owned company established in 1995 with a capital of Birr 14.9 Million. In accordance with "licensing and supervision of banking business proclamation no. 84/1994 "Of the National Bank of Ethiopia to undertake commercial banking activities. The bank obtained its license from National bank of Ethiopia on 20 September, 1995 and started normal business activities on the first of January 1996. Presently, the bank has the current paid up capital of more than ETB 4Billion birr and more than 4000 employees to operate through its head office in Addis Ababa and 400 area banks (branches) established within and outside of Addis Ababa out of which 26 Area Banks operating in the Bank's own building. Currently Dashen bank has $400+$ ATM machine and 780 merchant with POS throughout the country.(Dashen Bank 17th Annual report for the year 2013)

Dashen Bank provides different kind of commercial bank activities including:

To meet the needs of the emerging private sector for quality and dependable domestic and international banking services. customers.

To expand and diversify commercial banking services in response to the growing demands of

To contribute towards the economic and social development of the country

To operate profitably in a sustainable manner.

To mobilize all types of deposits (savings, demand , time, Hybrid Account, Saving plus Account, Modified Youth Saving, Interest plus bonus, Student account and current account Protection Scheme) and pay interest on interest bearing accounts.

$>\quad$ To provide loans and advances to its customers, including long-term investment/ project financing.

$>\quad$ To render domestic and international money transfer services.

$>\quad$ To provide international banking services such as:

$>\quad$ Imports operations

$>\quad$ Exports operations

$>\quad$ Handles foreign currency transactions, namely,

$>\quad$ Buying and selling foreign currency note.

$>\quad$ Encashment of VISA and MASTER card.

$>\quad$ Maintain and operating non-resident account. 
To provide deposit services in foreign currency for Ethiopian nationals and foreign nationals of Ethiopian origin provides advice on banking finance and investment to its customers.

\subsection{Statement of the problem}

Bank credit can be defined as money provided by the banks for eligible customers to support execution of legally formed profitable business or investment activities that have economic importance, with an agreement to pay back the principal with interest within the period specified in the loan contract. Dashen Bank is one of private banks in Ethiopia playing an important role in country's economy and social life. Among the various services provided by the bank, lending has been the primary activity for over a decade. It advances a large sum of its income to borrowers. It is equally true that bank loans, as they are profitable, equally risky. Bank loans fluctuate and influenced by the changes in the economic policy and the economy in general. It is very important for the banks to formulate and update their loan policies in order to minimize risk associated with them. There are a number of studies on credit risk management in Ethiopia:

Tibebu (2011) in his paper examine the impact level of credit risk management towards the profitability of selected commercial banks in Ethiopia in general. He argues that credit risk management has significant impact on profitability of banks of our country. He took seven selected banks such as Commercial bank of Ethiopia, Nib International bank,Dashen bank, Awash International Bank, Bank of Abyssinia, Wegagen Bank and United Bank.

Hagos (2010) in his study of credit management- A Case Study of Wegagen Bank Share Company in Tigray Region attempt to indicate the importance of credit management in financial institutions such as commercial banks, micro finances and others. Thus, the rationale behind undertaking the study is to deeply investigate the causes of credit management problems and to suggest the possible solutions that enable the bank to run its operation in a safest way as credit is known to be the main focus of all banks.

Solomon (2013) assesses credit risk management practice of Nib International Bank S. Cand find out that risk which emanates from credit is due to high degree of credit concentration in few sector and borrowers, the use of collateral as number one technique to alleviate credit risk and absence of proper evaluation model. He goes on to state lesser value for MIS, absence of advisory service, dependency of administration mechanism, override in appraisal process, absence of proper follow up and no formal way of penalizing loan officers is the major cause of credit risk in NIB international bank.

Tesfaye (2014) investigates factors influencing credit risk in the Ethiopian commercial banks. The main purpose of the study is to follow a comprehensive approach towards identifying credit risk influence factors. Yalemzewd (2013) assess credit management practice of Buna International Bank S.C and analyzed the process of accessing credit, credit control process and credit collection strategy against non-performing loan of the bank.

As mentioned above most of the researches are conducted on different private banks at National or Head office level in which large amount of their loans are dispersed to private business but this paper is conducted on Dashen Bank S.C at Branch Level.

The major issue of this paper is to assess and find out what tools and techniques are used at Lower edges of the bank and to what extent their current performance are supported by proper credit risk management policy, procedure and strategy. Loans are the most important resources held by banks. Lending activities require banks to make judgment related to the credit worthiness of a borrower. However, the judgments do not always prove to be accurate and the credit worthiness of a borrower may decline due to various factors. Consequently, banks face credit risks. Credit risk is the risk that obligations will not be repaid on time and fully as expected or contracted, resulting in a financial loss or non-performing loans. The borrower may fail to meet the terms of the underlining loan agreement so the major problems of Dashen Bank are financial loss or non-performing loan.

\subsection{Research Question}

This research was investigating the credit approval procedure and credit risk management of Dashen Bank S.C Mettu Branch Bank in order to find out:

Does the bank use appropriate credit policies and procedures? 
$>\quad$ What are the major causes of Nonperforming Loans?

$>\quad$ What are the sequences of procedures for borrowers whose payments are overdue?

$>\quad$ What effort is accepted by credit department after disbursement of loan made?

\subsection{Objective of the study}

It is important to conduct critical assessment of the variable factors, which determine approval of credit mechanism and evaluation of acceptability of loan request presented using appropriate standards. The objective of the study is described as follows.

\subsubsection{General Objective}

The general objective of the study is to assess the credit risk management practice Of Dashen Bank S.C Mettu Branch

\subsubsection{Specific Objective}

The specific objective of Dashen Bank S.C Mettu Branch is:

1. To assess the procedures that the bank has used to reduce the amount of non-performing loans in the past.

2. To identify the problems associated with the non-performing loans (NPLS) in Dashen Bank Mettu Branch.

3. To assess the problems associated with implementing policy manual of the bank.

4. To explore the essence of credit follow up and reviewing the follow up systems and timely settlement of loans.

\subsection{Significance of the study}

Since credit is the back bone of bank industry in generating income, the outcome of the study will help policy maker, loan processing and credit appraisal department, credit administration department and credit risk management department by forwarding relevant information from outcome of the study in order to improve their credit risk management practice.

Moreover, the study also have importance for other Ethiopian banks policy makers by providing empirical data that help in improving or formulating the policy environment for credit risk management practice of the banks. Also the research will be input for further study in the area of credit risk management practice.

\subsection{Delimitation/ Scope of the Study}

The focus of the research is assessment of credit risk management practice of Dashen Bank S.C Mettu Branch and the researcher mainly focuses on credit administration, credit appraisal, customer relationship managers department and related area at Branch office level, risk management department and consumer loan at branch level in order to gather relevant information about the area of study.

\section{Literature Review}

\subsection{Credit risk}

Beasens and Gestel (2009) defines credit risk as the risk that a borrower fails to pay and does not act according to their obligation to service debt. They state that the causes for the failure to pay could be incapability of the other party to pay or failure to pay on the due date. Besides they mentioned that by its character credit risk is the most apparent risk of a bank. In addition to this the writer characterize credit risk by ways of three aspect the first one is default risk is the possibility that payment is not issued at least within three Month this delay will happen due to Counterparts with a weak financial situation, high Debt burden, low and unstable income have a higher default probability, sector information and management quality. The second aspect is loss risk or loss given default (LGD) which is a fraction of exposure in the case of failure to pay and exposure risk is ambiguity on the accurate amount at risk at the very instant of a future default.

In the same way Singh (2013) states that another term for credit risk is default risk and defines it as the bank's risk of loss arising from a counterparty that does not make payments in accordance with his/her promise. He also points out credit risk is the earliest and the main source of risk in the banking sector. Credit risk encompasses both the possibility that a borrower will default by failing to repay principle and interest in timely manner, and the possibility that the credit quality of the obligor will deteriorate, leading to an economic loss 
(Ong, 2006). Credit risk occur when one of the counter parties to a transaction does not clear up in full either when the fund are outstanding or on some later date and it may result in bankruptcy of counterparty (C.Baker, 1998). According Anuj A. (2011), credit risk is delay of one's own obligation in accordance with Stetted contractual financial obligation within the deadline of payment by counter party. Credit risk is the possibility that debtors or borrowers incapability of paying its obligation in a way that predetermined contractual agreement made during credit approval process which adversely affect the working environment of the lender. Credit risk is defined as the probability that a bank borrower or counterparty will fail to meet its obligations in accordance with contracted terms Basel (2000). Credit risk arises whenever a lender is exposed to loss from borrower, counterparty, or an obligor who fail to honor their debt obligation as they have agreed and contracted Colquitt (2007).

The Basel (2001), defines credit risk as a chance when borrowers fail to repay their loan partially or fully due to different circumstances. It also state that the extent to which the bank exposed to higher credit risk will lead to unexpected financial crises and lower credit risk will minimize the probability of the crises because large amount of profit will be generated from this department of the bank

\subsubsection{Types of credit risk}

According to Brown and Moles (2014) there are two sub-types of credit risk country risk and industry risk which affect multinational enterprises.

\section{Country risk}

Arise from having contact to individuals and institutions in countries that have legal systems, business codes and standards that differ from those of the lender. There are four factors relevant to this. The first is political risk, which arises when a country's government is challenged externally or from within national borders. Political risk is more problematic in long-term lending agreements than for short-term transactions. The second is Economic risk, which arises from depressed or declining economic stability in a country. The third factor is currency risk, which always arises with cross-border lending. Finally, the fourth factor is the enforcement risk from the legal system in the debtor country. Because a creditor has to go through a foreign legal system, it has been known for debtors to use their domestic legal process to stand or attempt to avoid paying, claiming that rules from their home country apply.

\section{Industry risk}

This applies particularly when the domestic or international economy is in recession and the poor economic conditions particularly affect certain industries. Industry structure may have credit consequences because of the supply chain within which most firms operate. It is a form of concentration risk. According to Baesens \& Gestel (2009) Credit risk consists of pre-settlement and settlement risk.

\section{Pre-settlement risk}

Pre-settlement risk is incapability of borrower to perform their obligation through the life of loan repayment period. It can occur over long period of time from contractual period up to settlement. And when the borrower residence countries forbid and block all foreign payment.

\section{Settlement risk}

Settlement risk is the exchange of transaction through the involvement of third party this may create suitable environment for settlement risk because the default of the third party during the transaction will directly affect the other party (lender of bank). Longer time duration, payment in different time zone and different currency is the most important factor to increase settlement risk.

\subsection{Credit Risk Management}

According to Singh (2013) credit risk management includes all management function such as identification, measurement, monitoring and control of the credit risk exposure. The writer further indicated that for long term achievement of banking sector effective credit risk management practice is a vital issue in the current business environment and poor credit risk management policy will create serious source of crisis in the banking industry. According to Atakelt (2015) Credit risk management practice define as the process of analyzing and renewing Credit risk management documents and apply constantly in actual Credit granting process, Credit administration and monitoring and risk controlling process with suitable Credit risk environment, 
understanding and identification of risk so as to minimize the unfavorable effect of risk taking activities and the effectiveness of credit risk management process is dependent on different variables such as proper application of best Risk management documents, Staff quality, Credit culture, devoted top management bodies, sufficient training program, proper organizational structure, ample level of internal Control and Performance of intermediation function. This indicates that credit risk management includes different issues such as developing and implementing suitable credit risk strategy, policy and procedure, accurate identifications of risk, best credit granting process, credit administration, monitoring and reporting process determining and controlling the frequency and methods of reviewing credit policy and procedure and setting authority and responsibility clearly. Besides he mentioned that by establishing suitable credit risk environment, acceptable level of credit limit, best credit granting process, proper monitoring and controlling credit risk and optimizing risk return of a bank credit risk management develop credit performance.

Cebenoyan \& Strahan (2004) examine empirically how active management of credit risk using loan deal affects capital structure, lending, profits, and risk of banks. They find that banks which are Active in the loan sales market hold less capital and make more risky loans than other banks. They conclude that advances in credit risk management improve credit accessibility rather Than decrease risk in the banking system. The management of credit risk has become a key objective for all financial institutions across the world. The goal of credit risk management is to maximize a bank's risk-adjusted rate of return by maintaining credit risk exposure within acceptable parameters Basel (1999). According to Anuj A. (2011) through designing and implementing a Credit Risk Framework, Performing a Credit Risk Assessment, Building Credit Risk Scoring Models and Credit Risk Reporting control panel and Forecasting Loan Loss we can construct effective credit risk management and he also believe that most effective credit risk management focuses on processes, culture, people and organization because we are working with them. "Credit risk management includes both preventive and curative measure. Preventive measure comprise risk assessment, risk measurement, and risk pricing, early warning system to pick signal of future default in advance and undertake better credit portfolio diversification. The curative measure aim at minimizing post sanction loan losses through steps such as securitization, derivative trade, risk sharing and legal enforcement" (Jain, 2014, p3).

\subsection{Overall life cycle of credit risk management}

Whither the institution in to bankrupts or profitability depends on the level of credit risk management strategy and proper implementation credit process in each credit risk management life cycle. According to George, Sinba and Murat (2008) they put four levels of credit risk management life cycle:

1. Collect obligor (borrower) and loan data: Parties needed her is borrower, loan and external data. The key task and challenges of this stage is interpretation of financial information, system integration, getting the borrower and loan data, data quality and getting external rating data.

2. Compute credit risk: In this stage credit risk will be calculated in the form of risk rating of meaningful differential risk among different firms and exposure. The main task and challenges her is developing rating model, calculating the probability of default, rating approach, comprehensiveness of data, comprehensiveness of model, calculating loss given default (LGD), exposure at default (EAD) and expected loss (EL) are the major one.

3. Monitoring and managing risk rating: This stage is a stage of monitoring and managing the risk rating system. The main activity and challenges her is interface with internal collection, perform back testing of rating, reduction of manual dependency feedback and alert, develop workflow to manage approval of rating and ensure notification on external rating change.

4. Managing portfolio and allocation of capital: This level of credit risk management life cycle is the most difficult and challenging in the financial world today. The most important activities and challenges of this stage is compute and monitor portfolio risk, allow transfer of risk, reporting on risk, stress testing /scenario analysis and stress testing/back testing challenge are the most important activity expected to be performed at this level.

\subsection{General measurement principle of credit risk exposure}

"A bank should disclose balances of credit exposures, including current exposure and, where applicable, future potential exposure, by major categories." Basel (2000). According to Basel (2013 \& 2014) a bank's total Exposure Measure is the sum of the following exposures: (a) on-balance sheet exposures, (b) derivative exposures, (c) securities financing transaction exposures, and (d) other off-balance sheet exposures. The 
specific treatment for these four main exposure categories is defined below.

\section{a. On-balance sheet exposures}

Banks must include all on-balance sheet assets in their Exposure Measure including on-balance sheet derivative collateral and collateral for securities financing transactions (SFTs) (but excluding some of onbalance sheet derivative and SFT assets. 1 GAAP recognizes on-balance sheet fiduciary assets, these assets can be excluded from the Exposure Measure. Physical or financial collateral, guarantees or credit risk mitigation purchased are not allowed to reduce on-balance sheet exposures. On-balance sheet, non-derivative exposures are included in the Exposure Measure net of specific provisions and valuation adjustments (e.g. credit valuation adjustments).

\section{b. Derivative exposures}

Treatment of derivatives: derivatives create two types of exposure: (a) an exposure arising from the underlying of the contract and (b) a counterparty credit risk exposure. The leverage ratio framework uses the method set out below to capture both of these exposure types. Banks must calculate their derivatives exposures, including where bank sells protection using a credit derivative, as the replacement cost for the current exposure plus an add-on for potential

Total Exposure $=$ replacement $\operatorname{cost}(R C)+$ add-on

$R C=$ the replacement cost of the contract (obtained by marking-to-market), where the contract has a positive value.

Add-on = an amount for potential future credit exposure over the remaining life of the contract calculated by applying an add-on factor to the notional principal amount of the derivative.

\section{c. Securities financing transaction (SFT) exposure}

Securities financing transactions (SFTs) are included in the Exposure Measure according to the following treatment. The treatment recognizes that secured lending and borrowing in the form of SFTs is an important source of leverage and ensures consistent international implementation by recognizing the main differences across accounting frameworks

\section{d. Off balance sheet exposure}

This section explains the incorporation into the Exposure Measure for off-balance sheet (OBS) items, as defined under the risk-based framework. For example, the OBS items include commitments (including liquidity facilities), unconditionally cancellable commitments, direct credit substitutes, acceptances, standby letters of credit, trade letters of credit, failed transactions and unsettled securities (Basel, 2014).

\subsection{Operating under a sound credit granting process}

According to Saunders and Allen (2002) \& (Thomas (2002)) the expert analyzes five key factors, subjectively weights them, and reaches a credit decision:

1. Character: A measure of the reputation of the firm, its willingness to repay, and its repayment history e.g. age factor.

2. Capital: The equity contribution of owners and its ratio to debt (leverage). These are viewed as good predictors of bankruptcy probability. High leverage suggests a greater probability of bankruptcy.

3. Capacity: The ability to repay, which reflects the volatility of the borrower's earnings.

4. Collateral: In the event of default, a banker has claims on the collateral pledged by the borrower. The greater the priority of this claim and the greater the market value of the underlying collateral, the lower the exposure risk of the loan.

5. Cycle (or Economic) Conditions: The state of the business cycle; an important element in determining credit risk exposure, especially for cycle dependent industries.

\subsection{Principles for the Assessment of Banks' Management of Credit Risk}

Financial institutions are facing several problems due to lack of adequate credit risk management principles, 
proper implementation credit standards of borrower and counterparties and poor portfolio risk management or lack of attention to changes in economic or other circumstances that can lead to worsening in the credit standing of a bank's counterparties. Sound principles of banks credit risk management will be covered on five areas as follows Basel (2000).

Establishing an appropriate credit risk environment: The strategy of the bank should reflect the bank's tolerance for risk and the level of profitability the bank expects to achieve for incurring various credit risks. Such policies and procedures should address credit risk in all of the bank's activities and at both the individual credit and portfolio levels. Banks should identify and manage credit risk inherent in all products and activities.

Operating under a sound credit granting process: Banks must operate within sound, well defined credit granting criteria. These criteria should include a clear indication of the bank's target market and a thorough understanding of the borrower or counterparty, as well as the purpose and structure of the credit and its source of repayment. Kim (1987) state that Credit granting process involves an exchange between the supposed default risk of the credit application and possible returns from granting requested credit.

Maintaining an appropriate credit administration, measurement and monitoring process: Banks must monitor the condition of individual credits, including determining the adequacy of provisions and reserves with consistent rating system in nature, size and complexity of a bank's activities with information systems and analytical technique.

Ensuring adequate controls over credit risk: Banks must establish a system of independent, ongoing assessment of the bank's credit risk management processes and ensure that the credit-granting function is being properly managed and their credit exposure level.

The role of supervisors: Supervisors should conduct an independent evaluation of a bank's strategies, policies, procedures and practices related to the granting of credit and the ongoing management of the portfolio and couch practical limits to restrict bank exposures to single borrowers or groups of connected counterparties.

\subsection{Credit risk measurement}

Credit risk measurement relies on the lenders analytics and risk measurement tools rather than the borrowers. It also has three goals the first one is to limit the credit risk exposure that the lender accepts when extending the debt. The second goal is to insure that adequate compensation is earned for risk undertaking. It is concerned with the revenue and profit margin earned on the products and services that lenders provide. The third goal is to mitigate the credit risk exposure by structuring transaction to protect against loss as well as in to asset classes that can be marketed to third party investor Colquitt (2007). The risk measurement concerns the actual measurement of the risk in a risk grade or on a total portfolio. The measurement quantifies the actual default risk (probability of default), the loss risk (loss given default) and the exposure risk (exposure at default). A simple way of risk measurement is to learn from past data when available (Beasens and Gestel, 2009).

\subsection{Credit risk Models}

Risk model deals with the understanding and prediction of risk levels (Beasens and Gestel, 2009) Credit risk modeling methodologies allow a tailored and flexible approach to price measurement and risk management. (Basel, 1999)

\section{Value at Risk Model (VAR)}

It is one of the newer risk management tools. The Value at Risk (VAR) indicates how much a firm can lose or make with a certain probability in a given time horizon. VAR summarizes financial risk inherent in portfolios into a simple number. Though VAR is used to measure market risk in general, it incorporates many other risks like foreign currency, commodities, and equities. (Thirupathi K.\& M. Manojkumar, 2013)

Credit VAR models can be gathered in two main categories: 1) Default Mode models (DM) and 2) Mark-toMarket (MTM) models. In the former, credit risk is identified with default risk and a binomial approach is adopted. Therefore, only two possible events are taken into account: default and survival. The latter includes all possible changes of the borrower creditworthiness, technically called "credit migrations". In DM models, credit losses only arise when a default occurs. On the other hand, MTM models are multinomial, in that losses arise also when negative credit migrations occur (Altman, 2006).

\section{The Merton model}

The basic intuition behind the Merton model is relatively simple: default occurs when the value of a firm's 
assets (the market value of the firm) is lower than that of its liabilities. The payment to the debt holders at the maturity of the debt is therefore the smaller of two quantities: the face value of the debt or the market value of the firm's assets. Under these models, all the relevant credit risk elements, including default and recovery at default, are a function of the structural characteristics of the firm: asset levels, asset volatility (business risk) and leverage (financial risk). The RR is therefore an endogenous variable, as the creditors' payoff is a function of the residual value of the defaulted company's assets Altman (2006). The probability of a firm going bankrupt depends crucially on the beginning period market value of that firm's assets relative to its outside debt and the volatility of the market value of a firm's assets (Altman \& Saunders, 1998).

\section{Credit Metrics model}

Credit Metrics is a tool for assessing portfolio risk due to changes in debt value caused by changes in obligor credit quality. We include changes in value caused not only by possible default events, but also by upgrades and downgrades in credit quality. Also, we assess the value-at-risk (VAR) the volatility of value not just the expected losses. Importantly, we assess risk within the full context of a portfolio. We address the correlation of credit quality moves across obligors. This allows us to directly calculate the diversification benefits or potential over-concentrations across the portfolio. In addition, Credit Metrics allows us to capture certain market risk components in our risk estimates. These include the market driven volatility of credit exposures like swaps, forwards, and to a lesser extent, bonds. J.P Morgan (1997).

\section{Internal Rating System}

An internal rating system assists financial institutions to manage and control credit risks they face through lending and other operations by grouping and managing the creditworthiness of borrowers and the quality of credit transactions. Thirupathi K. \& M. Manojkumar (2013)

Capital market looks to credit rating as a determinant of an obligor's financial health. Rating agencies use different grading system to rank borrower according to their ability to service their obligations (Ong, 2006).

\subsection{Credit scoring System}

According to Hussein \& John (2011) Credit scoring has been regarded as a core appraisal tool in which the idea of reducing the probability of a customer defaulting, which predicts customer risk, is a new role for credit scoring, which can support and help maximize the expected profit from that customer for financial institutions, especially banks. One of the most important things, to classify a bank's customers, as a part of the credit evaluation process to reduce the current and the expected risk of a customer being bad credit, is credit scoring. Hand \& Jacka, (1998, p. 106). Credit scoring is purely judgmental approach in which credit analyst decision is based on five Cs (i.e. character, capacity, capital, collateral and condition, Thomas (2002).

According to Beasens and Gestel (2009) Credit scoring is a credit risk management technique that analyzes the borrower's risk. In its early meaning, "credit scores" were assigned to each customer to indicate its risk level. The more highly discriminative the scoring system, the better are the customers ranked from high to low risk. Commonly focuses on the values of the $5 \mathrm{Cs}$ of a customer (i.e., Character, Capital, Collateral, Capacity and Condition.). Credit scoring is the set of decision models and their underlying techniques that aid lenders in the granting of consumer credit. These techniques assess, and therefore help to decide, who will get credit, how much credit they should get, and what operational strategies will enhance the profitability of the borrowers to the lenders (Thomas, 2000). The judgmental techniques rely on the knowledge and both past and present experience of credit analysts, who evaluate the required requisites, such as the personal reputation of a client, the ability to repay credit, guarantees and client's character. (Abdou, El-Masry \& Pointon, 2007). Credit scoring is mechanical system for analysis of the loan applicant and used to increase the correctness in the approval of loans to creditworthy customers, which can result in increased profits or rejection of those customers who are not creditworthy. The main reasons for the use of credit scoring are to reduce bad debts and to improve operational efficiency (Janeska, Sotiroski, \& Taleska, 2014). The main aspect generally used in credit scoring models include the borrowers" personal characteristics such as income, age, gender, education, occupation, region, time at present address, residential status, marital status, and followed by the borrower' banking relationship such as collateral value, loan duration, time with bank, number of loans, and current account (Marian G. \& Fotini G., 2010, p.15).

According to Beasens and Gestel (2009) Different customer scoring stage are listed as follows: Marketing score: a marketing activity aims to reduce the cost of customer acquisition and to minimize customer 
inconvenience and dissatisfaction. Application score: Application scoring systems summarize all applicant information into one overall score measuring the creditworthiness of loan applicants in order to predict the probability of repayment problem. Fraud score: simply by observing and counting the number of days in payment arrears, to claim as fraudulent or a credit application as containing fraudulent information. Performance score: The goal of performance scoring is to monitor the existing portfolio, its future performance and losses. Behavioral score: Behavioral scoring analyzes the risk of existing customers based on their recently observed behavior once credit has been granted, banks can subsequently start to monitor the repayment and financial behavior of their customers. It allows lenders to make better decisions in managing existing clients by forecasting their future performance Thomas (2002). The behavior score analysis the customer's previous payment and purchase behavior as well as the customer's social demographic (Charlotte \& Camilla, 2010). Early warning score: Early warning systems aim to early detect potential crises with counterparts. These counterparts are put on a watch list for closer inspection and follow up. Collection score: Collection scoring is a decision support tool to manage bad debt.

One rank orders customers already in payment arrears based on the probability of successfully collecting the outstanding debt. Profit score: Developing customer level profit scoring models is typically very complex because of several practical implementation issues. Direct and indirect benefits and costs need to be considered and also the timing of the cash flows and the corresponding discount factors need to be taken into account. Credit lenders wish to change from minimizing the risk of a consumer defaulting to maximizing the profit a consumer brings them Thomas (2002).

\subsection{Credit Risk Mitigation}

According to Dohnal (2008) Credit Risk Mitigation (CRM) defined as a mechanism used by different credit institution in order to minimize their credit risk related with exposure which the institution continuous to hold. He also further point to that credit risk mitigation techniques can be distinguish in to two parts the first one is funded credit protection which includes real estate and financial instrument. The reduction of the credit risk exposure of a credit institution draw from the right of the credit institution in case of default to liquidate or retain, to obtain transfer or appropriation of certain assets, to reduce the amount of the exposure and to replace the amount of the exposure. The other one is unfunded credit protection which includes guarantee. The reduction of the credit risk exposure of a credit institution derives from the responsibility of a third party to pay an amount in the occasion of borrowers incapability to pay their loan or on the incidence unexpected events.

\subsection{Credit Risk Mitigation technique}

"A bank should disclose the effect of credit risk mitigation techniques, including collateral, guarantees, credit insurance and legally enforceable netting agreements". (Basel 2000)

\section{Funded credit protection}

\section{a. Collateral}

Collateral is an asset that serves as security against counter party risk. Anderson and Joeveer(2014)

A collateralized transaction is a transaction where the credit exposure or potential credit exposure of the credit institution to a counterparty is hedged in whole or in part by collateral posted by the counterparty or by a third party on behalf of the counterparty. Basel (2004) Collateralized credit exposures must have a risk biased exposure amount less than the same credit exposure without credit protection. The collateral can be in the form of real estate, receivable and other form of physical collateral. Dohnal (2008)

\section{b. On-balance sheet netting}

According to Basel (2004) Banks where legally enforceable netting arrangement for loans and deposits they may calculate capital requirement on the bases of net credit exposure. The claim between the credit institution and counter party may be recognized. They also indicated that Master netting agreements covering repurchase transactions and/or securities or commodities lending or borrowing transactions and/or other capital market driven transactions.

\section{Unfunded credit protection}

The amount that the safety provider has carried out to pay in the event of the default or non-payment of the borrower or on the event of other specified credit situation is the value of unfunded credit protection. where 
the amount that the protection provider has carry out to pay is not higher than the exposure value, the value of the credit protection shall be reduced by $40 \%$; where the amount that the protection provider has carry out to pay is higher than the exposure value, the value of the credit protection shall be no higher than $60 \%$ of the exposure value Basel (2004)

\section{a. Guarantees}

A guarantee must represent a direct claim on the guarantor with the extent of the cover being clearly defined and unquestionable. A guarantee must be irrevocable; there must be no clause in the guarantee that would allow the guarantor to cancel unilaterally the cover of the guarantee or that would increase the effective cost of cover as a result of deteriorating credit quality in the guaranteed exposure. A guarantee must also be unconditional; there should be no clause in the guarantee outside the direct control that could prevent the guarantor from being obliged to pay out in a timely manner in the event that the original counterparty fails to make the due payment. The indirect guarantee covers all credit risk elements of the claim; both the original guarantee and the indirect guarantee meet all the operational requirements for guarantees except that the indirect guarantee need not be direct and explicit to the original claim. Basel (2008)

\section{b. Loan Commitments}

A loan commitment is a facility which gives the obligor the option to borrow at his own discretion. In practice, this essentially means both a loan (equal to the amount currently drawn on the line) and an option to increase the amount of the loan up to the face amount of the facility. The counterparty pays interest on the drawn amount, and a fee on the undrawn amount in return for the option to draw down further. For these exposures three factors influence the revaluation in future rating states: the amount currently drawn; expected changes in the amount drawn that are due to credit rating changes; and the spreads and fees needed to revalue both the drawn and undrawn portions. All of these factors may be affected by covenants specific to a particular commitment. J.P Morgan (1997)

\subsection{Tools of Credit Risk Management}

According to Sunitha and J. K. Raju (2013), Thirupathi \& M. Manojkumar (2013) Bhaskar (2014) and Nayan \& M.Kumaraswamy (2014) the tools through which credit risk management is carried out are:

Exposure Ceilings: Prudential Limit is linked to Capital Funds -say 15\% for individual borrower entity, 40\% for a group with additional 10\% for infrastructure projects undertaken by the group, Threshold limit is fixed at a level lower than Prudential Exposure; Substantial Exposure, which is the sum total of the exposures beyond threshold limit should not exceed $600 \%$ to $800 \%$ of the Capital Funds of the bank (i.e. six to eight times).

Review/Renewal: Multi-tier Credit Approving Authority, constitution wise delegation of powers, Higher delegated powers for better-rated customers; discriminatory time schedule for review/renewal, Hurdle rates and Bench marks for fresh exposures and periodicity for renewal based on risk rating, etc are formulated.

Risk Rating Model: Set up comprehensive risk scoring system on a six to nine point scale. Clearly define rating thresholds and review the ratings periodically preferably at half yearly intervals. Rating migration is to be mapped to estimate the expected loss

Risk based scientific pricing: Link loan pricing to expected loss. High-risk category borrowers are to be priced high. Build historical data on default losses. Allocate capital to absorb the unexpected loss.

Portfolio Management: The need for credit portfolio management emanates from the necessity to optimize the benefits associated with diversification and to reduce the potential adverse impact of concentration of exposures to a particular borrower, sector or industry. Stipulate quantitative ceiling on aggregate exposure on specific rating categories, distribution of borrowers in various industry, business group and conduct rapid portfolio reviews.

Loan Review Mechanism: This should be done independent of credit operations. It is also referred as Credit Audit covering review of sanction process, compliance status, and review of risk rating, pickup of warning signals and recommendation of corrective action with the objective of improving credit quality. It should target all loans above certain cutoff limit ensuring that at least $30 \%$ to $40 \%$ of the portfolio is subjected to LRM in a year so as to ensure that all major credit risks embedded in the balance sheet have been tracked. 


\subsection{Empirical studies}

Different researchers were conducted on this area of studies in different financial institutions. Yang Wang, (2013) find out that the key principles in credit risk management are establishment of a clear structure, allocation of responsibility and accountability, processes have to be prioritized and disciplined, responsibilities should be clearly communicated and accountability assigned on his research title Credit Risk Management in Rural Commercial Banks in China. Atkilti (2015) in his study find out that Credit risk, liquidity risk and operational risk are the three important types of risks the banks mostly facing. The three widely used Risk identification method were identified and ranked as Financial Statement Analysis firstly and followed by audit and physical inspection and then internal communication. The study further confirmed that four aspects of Basel's Credit risk management principles explain a significant level of variation on Credit risk management practice of Ethiopian commercial banks. Furthermore, Establishing an appropriate Credit risk environment and Ensuring adequate Controls over credit risk were found to be the most influential variables on level of Credit risk management practice. It is finally observed insignificant difference between public and private commercial banks in all aspect of Credit risk management principles and practice. Girma (2011) point out on his study credit risk management and its impact on performance in Ethiopian commercial banks that the default ratio of any bank in Ethiopia depends on credit risk management quality of the institution. Solomon (2013) studied credit risk management practice of Nib International Bank of Ethiopia and in his assessment the researcher come across that factors lead to wrong decision making and increase NPL level of the bank are concentration of credit in few sector and borrower, collateral as number one technique of credit risk management, absence of credit risk model of credit portfolio, lesser attention for MIS and advisory service to customers and absence of proper follow up. Tibebu (2011) examined that credit risk management and profitability of commercial banks in Ethiopia. Find out that Both nonperforming loan ratio and capital adequacy ratio has a negative impact on profitability's of commercial banks in Ethiopia. He also state that the impact level of nonperforming loan ratio is negative which means, a single unit increase in nonperforming loan ratio leads in (.594077) decrease of profitability of commercial banks of Ethiopia. Tesfaye (2012) study factors influencing the level of credit risk in the Ethiopian commercial banks. The study find out that quantity of risk and quality of risk management related variables has got much influence on the credit risk level of banks. Nevertheless, risk direction related measures, which are mostly external focus, have limited influence on credit risk. More specifically the variation in the effect of stock and flow measures entails banks to further enhance mostly two of Basel principles: operating under a sound credit granting process and maintaining an appropriate credit, administration, measurement and monitoring process. Akotey J.O. (2012) the study has examined the credit risk management of selected rural banks in Ghana and has discovered that credit risk management plays a significant and dynamic role in the business of rural banking. The researcher find out sampled ruler commercial banks have poor credit risk management practices and hence the high levels of the non-performing loans in their loans portfolios. Despite the high levels of the NPLs, their profit levels keep rising as an indication of the transfer of the loan losses to other customers in the form of large interest margins. Therefore the findings indicate a significant positive relationship between non-performing loans and rural banks' profitability informative that, there are higher loan losses but banks still earn profit. Bajpai et.al. (2015) The researcher find out that BPR Ltd has a credit management system however it needs to be reviewed and adopted more to current Rwandan environment. The researcher also indicated that there is a direct relationship between credit risk management and profitability of commercial banks and recommended that BPR Ltd should review and improve its credit policy and adopt it to Rwandan market and context and BPR Ltd should provide continuous training and bring up to date its staffs.

\section{Research Methodology}

\subsection{Research design}

In this study the researcher uses descriptive type of research and the researcher tries to describe the credit risk management practice, and the controlling mechanism and measurement tools and techniques of Dashen Bank S.C Mettu Branch. Besides, the study deeply described these variables by using both primary and secondary data. The primary data was collected by distributing structured questioner to credit administration and appraisal department, consumer loan, risk management and loan recovery department officers and secondary data from reports (in order to know the progress of NPL), credit policy and procedures, central bank directive and other relevant document was used to analyze the extent of implementation. Finally, the collected data from both primary and secondary data was analyzed, summarized, concluded and recommended accordingly. 


\subsection{Types of Data Collected}

Both primary and secondary sources have been used throughout this research paper. The main inputs of primary sources are direct personal interviews and observations. As secondary source company manual, annual reports, various literature reviews and different loan files have been used.

\subsection{Data Gathering Instrument}

Firstly, the data has been be collected by using structures questionnaire for the staff members. Secondly, the interview has been made with the manager of the bank.

\subsection{Population and Sample Design}

The student researcher's has used selective sampling method based on this 15 out of 20 total populations was used.

\subsection{Sampling Design}

Since the target population on this study was employees of Dashen Bank S.C of Mettu Branch office the student researchers used 15 samples from 20 employees has been selected to conduct an interview and questionnaire

\subsection{Sample Method}

The sample method that has been use in the research is purposive sampling method from loan department. Structured interview is held with staff members. The questionnaire methods are used to combine qualitative and quantitative data collection using structured questionnaires and few open-ended questions

\subsection{Method of Data Analysis}

After the data required for the study are collected Descriptive statistics methods like charts and tables are used to present the data and statistically figures like percentages have been use for data presentation and analysis. Beside qualitative data are also used accordingly.

\section{Data Presentation and Analysis}

The primary objective of commercial banks like any other business institution is to grow and survive. This can mainly be achieved by making profit. In the case of banks, profit is a function of both the volume and the quality of loan, among others; good quality of credit can only be considered as a good source of profit. The effect of poor quality loans is not limited to that of affecting the profit of one particular bank but has an effect that extends itself in to the economy at large. Hence, prudent bank is concerned about the quality of their loans. This study is concerned with the Credit Risk Management and Practice of Dashen Bank S.C the case of Mettu Branch. In this Chapter both primary \& secondary data sources. The primary data was collected through questionnaire, interview and researcher's observations. The secondary data collected from different literatures, manuals and reports of the bank. From a target population of 20 staffs, questionnaires were distributed to 15 staffs of the bank judgmentally, all (100\%) had completed and returned. So, the following analysis and discussions are done on the collected data from the questionnaires. The purpose of this section is to assess the credit practices and management of the bank. The major findings from the responded questionnaire are compared and presented here under by respective questions.

\section{Analysis of Responses Given by the Loan Department Start}

Table 1. Background of Respondents

\begin{tabular}{|c|c|c|c|}
\hline Item & Responses & Number of start & Percentage \\
\hline \multirow[t]{5}{*}{ Level of education } & Diploma & 1 & 6.7 \\
\hline & 1st Degree & 14 & 93.3 \\
\hline & Above 1st Degree & - & - \\
\hline & Other & - & - \\
\hline & Total & 15 & $100 \%$ \\
\hline \multirow[t]{7}{*}{ Status } & Top management & - & - \\
\hline & Senior management & - & - \\
\hline & Middle Management & 2 & 13.3 \\
\hline & Line Management & 9 & 60 \\
\hline & Other clerical & 4 & 26.7 \\
\hline & Non clerical & - & - \\
\hline & Total & 15 & $100 \%$ \\
\hline
\end{tabular}




\begin{tabular}{|l|c|c|c|}
\hline \multirow{3}{*}{ Work experience } & Below five years & 8 & 53.33 \\
\cline { 2 - 4 } & 5-10 Years & 5 & 33.33 \\
\cline { 2 - 4 } & Above 10 years & 2 & 13.33 \\
\cline { 2 - 4 } & Total & 13 & $86.6 \%$ \\
\hline
\end{tabular}

Source: Primary Survey.

The staff educational level is very attractive as $100 \%$ of them have either Diploma or BA Degree and these shows that the Banks has qualified staff members. The Branches having a good loan portfolio has a credit Structure as Branch office.

Table 2. Loan Application Processing

\begin{tabular}{|l|c|c|}
\hline \multicolumn{1}{|c|}{ Item } & Reponses \\
\hline $\begin{array}{l}\text { How long will it take to process a loan } \\
\text { application? to give loan application? }\end{array}$ & Number & Percentage \\
\hline Below 7 days & 5 & 33.3 \\
\hline 8-14 days & 6 & 40 \\
\hline 15-21 days & - & - \\
\hline 22-28/30 days & 4 & 26.7 \\
\hline Above one month & - & - \\
\hline Total & 15 & $100 \%$ \\
\hline
\end{tabular}

Source: Primary survey.

As per the above table $40 \%$, of the respondents replied that within 8-14 days a given loan application can be processed and finalized, while $33.3 \%$ of respondents said that loan application can be processed below 7 days, but $26.7 \%$ of them agreed as 8-14 days. In addition the respondents also mentioned that depending on the nature and merit of the loan, the processing Period will vary.

Table 3. Granted Loan Taking Collaterals

\begin{tabular}{|l|c|c|}
\hline \multicolumn{1}{|c|}{ Item } & & Response \\
\hline $\begin{array}{l}\text { Are there loans, which are granted collaterals? } \\
\text { without taking collaterals? }\end{array}$ & Number & Percentage \\
\hline Yes & 11 & 73.3 \\
\hline No & 4 & 26.7 \\
\hline Total & 15 & $100 \%$ \\
\hline
\end{tabular}

Source: Primary survey.

As showed on the above table, 4 respondents, which are $26.7 \%$ of the sample size have viewed that loans granted without taking collateral that is granted to prominent customer on clean basis (a loan with out or partial collateral). On the other hand, 11 respondents, which are $73.3 \%$ of the respondents, replied that there is a Consideration of collateral before extending the loan.

Table 4. Loan Approval Procedures of the Bank

\begin{tabular}{|l|c|c|}
\hline Do you believe the procedure followed for loan & \multicolumn{2}{|c|}{ Respondents } \\
\cline { 2 - 3 } approval by the bank is satisfactory? & No. & $\%$ \\
\hline Yes & 15 & - \\
\hline No & - & 100 \\
\hline Total & 15 & 100 \\
\hline
\end{tabular}

Source: Primary survey.

From the above there is a clear indication that $100 \%$ of the respondents largely viewed that they are satisfied with the procedure followed for loan approval by the bank is satisfactory.

Table 5. Implementing Policy Manual of Banks as Desired

\begin{tabular}{|c|c|c|}
\hline $\begin{array}{l}\text { Are there problems as associated with } \\
\text { implementing policy manual of the bank? }\end{array}$ & Number & Percentage \\
\hline Yes & 10 & $66.6 \%$ \\
\hline No & 5 & $33.4 \%$ \\
\hline Total & 15 & $100 \%$ \\
\hline
\end{tabular}

Source: Primary survey.

The above table indicates $66.6 \%$ of the respondents for question replied that there are no problems associated with the policy manuals, but $33.4 \%$ said that there is some problem associated with it.

The following are the factors and reasons behind the respondents.

The reason for the factor is the policy manual is set as per the rules and regulations set by the controller 
Bank or Ethiopia, i.e. National Bank of Ethiopia (NBE). So the Bank implements the policy manual as desired.

$>$ Misinterpretation of the manual deliberate violation some time the manual gets abused by the management the manual fails to address newly emerged problems due to lack of continuous update.

The engineering department estimation is net practical by other bank and there is a challenge for implementation because of under estimation of collateral.

Table 6. Detailed Financial Analyses before Extending the Loan

\begin{tabular}{|l|c|l|}
\hline & \multicolumn{2}{|c|}{ Reponses } \\
\hline $\begin{array}{l}\text { Does the bank assess borrowers past financial history, credit } \\
\text { worthiness and perform detailed financial analysis before }\end{array}$ & Number & Percentage \\
\hline Yes definitely & 4 & 26.7 \\
\hline Yes to some extent & 10 & 66.6 \\
\hline Not at all & -- & - \\
\hline I am not quite aware of it & 1 & 6.7 \\
\hline Total & 15 & $100 \%$ \\
\hline
\end{tabular}

Source: Primary survey.

As indicated above 26.7\%) of the respondents replied that 'yes definitely' for the question the bank assess borrowers past financial history, Credit worthiness and perform detailed financial analysis before extending the loans 10 $(66.6 \%)$ and $1(6.7 \%)$ of the respondent answers that 'yes to some extent' and not quite aware of it respectively.

Table 7. Distributions of Loans and Advances by Sectors

\begin{tabular}{|l|c|c|}
\hline & Response & Rank \\
\hline $\begin{array}{l}\text { From the loans and advances granted to the } \\
\text { customer in which sector dose the bank usually } \\
\text { focus? }\end{array}$ & Domestic trade and service sector & $1^{\text {st }}$ \\
\hline \multirow{5}{*}{} & service & $2^{\text {nd }}$ \\
\cline { 2 - 3 } & Manufacturing & $3^{\text {d }}$ \\
\cline { 2 - 3 } & $\begin{array}{c}\text { Building and construction } \\
\text { construction }\end{array}$ & $4^{\text {th }}$ \\
\cline { 2 - 3 } & Export & $5^{\text {th }}$ \\
\cline { 2 - 3 } & Import & $6^{\text {th }}$ \\
\cline { 2 - 3 } & Transportation & $7^{\text {th }}$ \\
\hline
\end{tabular}

Source: Primary survey.

All of the respondents respond that, from the total loans and advances granted of the customers, Domestic Trade and Services sector is usually the bank focused and followed by Manufacturing, Building and Construction, Export, Import, transportation and Agricultural Sector. From the above observation we can conclude that the bank emphasized on Domestic Trade and Service due to business viability and high demand on the sector.

The following are the factors and reasons behind the respondents:

$>\quad$ Most of the customer request fall under this sector because of the capacity and overall Level of economy this category.

$>\quad$ You cannot give exact justification on the matter as things depends on external and internal factors for the purpose of ranking Domestic trade and service, Manufacturing, Trade and service, Building and Construction, Import and Expert.

Because the sector has un interpreted Demand or not seasonal as far as it provides consumable goods

The shares are given to each sector based on their past demand credit history.

Table 8. Techniques and Procedure of Credit Follow Up Designed and Implemented by the Bank

\begin{tabular}{|c|c|c|}
\hline \multicolumn{2}{|c|}{ Responses } & Percentage \\
\hline $\begin{array}{c}\text { Is there any credit follow up techniques and procedure } \\
\text { designed and implemented by the bank? }\end{array}$ & Number & $100 \%$ \\
\hline Yes & 15 & - \\
\hline No & - & $100 \%$ \\
\hline Total & 15 & \\
\hline
\end{tabular}

Source: primary survey. 
From the above table 4.8 indicates that $100 \%$ of respondents replied that there is credit follow up techniques and procedures designed and implemented by the bank.

The following are the factors and reasons behind the responds answer "yes "

$>\quad$ After loan is booked and have explicitly loan policies and ongoing risk analysis processing and monitoring employ to entertain a minimum risk by using the guiding procedures.

$>\quad$ Programmed visits to the work place of borrow.

$>\quad$ If is a project loan, periodical visit to check whether the loan is going according to the action plan and the loan is targeted to the intended purpose or not.

$>\quad$ Sometimes the head office credit manager and credit follow up section work together to further consolidate the follow up processes.

Table 9. The Follow Up Mechanism of Your Customer After Granting the Loan

\begin{tabular}{|l|c|c|}
\hline $\begin{array}{l}\text { Do you have any follow up mechanism of } \\
\text { your customer after granting the loan? }\end{array}$ & Number & Percentage \\
\hline Yes & 12 & $80 \%$ \\
\hline No & 3 & $20 \%$ \\
\hline Total & 15 & $100 \%$ \\
\hline
\end{tabular}

Source: Primary Survey.

As per the above table $80 \%$ of the employees respondent reply saying yes' regarding the follow up mechanism of your customer after grating the loan and the rest $20 \%$ Of them are saying 'NO' regarding to follow up mechanism of their customer after granting the loan.

Table 10. The Follow up Time Schedule of Your Customers after Granting Loan

\begin{tabular}{|c|c|c|c|}
\hline \multicolumn{1}{|c|}{ Item } & Response & \multicolumn{2}{|c|}{ Rank } \\
\cline { 2 - 4 } $\begin{array}{l}\text { What often the follow up } \\
\text { mechanisms of your customer } \\
\text { after granting the loan? }\end{array}$ & Monthly & 9 & $60 \%$ \\
\hline & & 1 & \\
\hline & Quarterly & - & \\
\hline & Semi annually & - \\
\hline & Annually & - \\
\hline
\end{tabular}

Source: Primary Survey

As per above table the follow up mechanism your customer after granting the loan, $60 \%$ of the respondent are monthly and the rest of them $6.67 \%$ respondent respond quarterly $6.67 \%, 6.67 \%$ Suddenly and others $6.67 \%$.

The following are the factors and reasons behind the respondents:

$>\quad$ Reports regarding the loans are prepared by the Area Bank monthly and these reports are also viewed by status at the loans are determined by the head office credit follow up section and therefore reports are prepared for the higher officials to control department monthly.

We could not be certain that all granted loans will be $100 \%$ sure to be collected so we will start following the loan status or the customers from the very beginning.

\section{Mechanism Order to return loan}

I Extension of life of loan

I Rearrangement of loan structures

I All Mechanisms to collect the loan
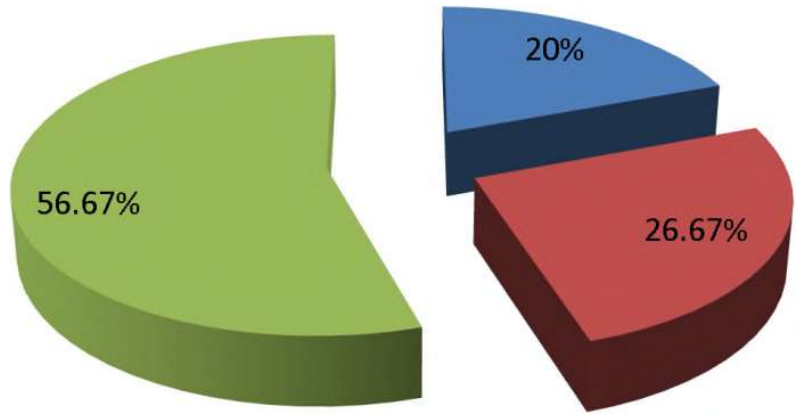

Figure 1. Mechanisms of Preventing NPLS

Source: Primary Survey. 
Figure 1 indicates that $56.67 \%$ of the respondents replied that the bank used all mechanisms in order to collect the loan, but $26.67 \%$ of the respondents said that rearrangement of loan structure as a major mechanism. Some of the respondents mention that other mechanism such as taking legal action and sale of mortgage properties as last option. In addition as per the interview conducted for question no 4, regarding the preventive measure Dashen Bank S.C Mettu Branch has taken an action to control or minimize the banks non-performing loan in the past, and also they suggested that setting corporate targets to reduce NPLs to a single digit number, encouraging and closely following up each organ towards materialization of the target, undertaking follow up through visits and consultation, evaluation of the quality of the credit process as well as compliance with the bank's policy and applying proper work out loan practice has done as a measure to minimize NPL in the past.

Table 11. Provision NPL Sufficient in relation to its Respondent

\begin{tabular}{|c|c|c|}
\hline $\begin{array}{c}\text { Do you think the level of provision for NPL held by } \\
\text { Dashen Bank S.C Mettu Branch is sufficient in relation } \\
\text { to its NPL? }\end{array}$ & Number & Percentage \\
\hline Yes & 15 & $100 \%$ \\
\hline No & - & - \\
\hline
\end{tabular}

Source: Primary Survey.

According to Table $4.11100 \%$ of the respondents said that the bank holds sufficient provision for NPLs as per the directive of NBE which is always inspected by its external auditors and the regulatory organ (NBE).

The provision is made in proportion to the amount of NPL Provision held by Dashen Bank S.C Mettu Branch is sufficient because the amount of provision is considered.

Table 12. Causes of Nonperforming Loan at Borrower Level

\begin{tabular}{|l|c|c|}
\hline Item & Response & Rank \\
\hline \multirow{3}{*}{$\begin{array}{l}\text { What are the major Causes of } \\
\text { nonperforming loan at borrower } \\
\text { level? }\end{array}$} & Diversion of the Borrower fund to other purpose & $1^{\text {st }}$ \\
\cline { 2 - 3 } & Lack of proper businesses plan & $2^{\text {nd }}$ \\
\cline { 2 - 3 } & Willful default/ un willingness to pay & $3^{\text {rd }}$ \\
\cline { 2 - 3 } & Contingencies at borrower of death or sick & $4^{\text {th }}$ \\
\cline { 2 - 3 } & Insufficient credit awareness & $5^{\text {th }}$ \\
\cline { 2 - 3 } & Unwilling customer to disclose the information required & $6^{\text {th }}$ \\
\hline
\end{tabular}

Source: Primary Survey.

The above Table indicates, $75 \%$ of the respondents, replied that due to diversion of the borrowed fund to other than initially intended purposes stands $1^{\text {st }}$, while as per $20 \%$ of the respondents believe that lack of proper business plan takes the $2^{\text {nd }}$ place. Besides, some customers intentionally will not pay their loan and this holds the lowest percentages which is $5 \%$ stands at $3^{\text {rd }}$ place.

Table 13. Causes of Non-performing Loan at Bank Level

\begin{tabular}{|c|l|c|}
\hline Item & \multicolumn{1}{|c|}{ Reasons } & Rank \\
\hline $\begin{array}{l}\text { What is the major cause of nonperforming } \\
\text { Loan at bank Level? }\end{array}$ & $\begin{array}{l}\text { Lack of Continuous follow-up and proper risk } \\
\text { assessment }\end{array}$ & 2nd \\
\cline { 2 - 3 } & $\begin{array}{l}\text { Lack of Consultation and Communication with } \\
\text { defaulter }\end{array}$ & 3rd \\
\cline { 2 - 3 } & Problems associated with loan eligibility criteria & 4th \\
\cline { 2 - 3 } & $\begin{array}{l}\text { Mistake on estimation of collateral and evaluating } \\
\text { the borrower's financial reports }\end{array}$ & 5th \\
\cline { 2 - 3 } & $\begin{array}{l}\text { Lack of sufficient credit information from other } \\
\text { commercial Banks } \\
\text { from other commercial banks }\end{array}$ & \\
\hline
\end{tabular}

Source: Primary Survey

From the above table, lack of continuous follow up and proper risk assessment is the first and the most major cause of nonperforming loan at bank level. Followed by the bank consultation and communication with defaulter, problems associated with loan eligibility criteria, mistake on estimation of Collateral and evaluating the borrower's financial report and lack of sufficient credit information from other Commercial banks. 
Table 14. Causes of Nonperforming Loan at Economic Level

\begin{tabular}{|l|c|c|}
\hline Item & Response & $1^{\text {Rank }}$ \\
\hline $\begin{array}{l}\text { What are the major causes of non- } \\
\text { performing loans at economic level? }\end{array}$ & $\begin{array}{c}\text { Weak economic plan and strategy } \\
\text { implementation }\end{array}$ & $1^{\text {st }}$ \\
\hline & $\begin{array}{c}\text { Change in fiscal and monetary } \\
\text { policies }\end{array}$ & $2^{\text {nd }}$ \\
\hline & Political power of the borrower & $3^{\text {rd }}$ \\
\hline & Unstable political situation & $4^{\text {th }}$ \\
$5^{\text {th }}$ \\
\hline
\end{tabular}

Source: Primary Data

The Above Table shows that most of the respondents replied weak economic plan and strategy implementation as a major $\left(1^{\text {st }}\right)$ cause at economic level. On the other hand, change in fiscal and monetary policies by government could result in high inflationary conditions stands in the $2^{\text {nd }}$ place. The rest of the respondents said excessive government interventions are the causes of NPL at economic level stands at $3^{\text {rd }}$.

\subsection{Analysis of Interview Questions}

This topic discusses the interview questions that are forwarded to staffs of Dashen Bank S.C Mettu Branch who are engaged in Credit Department particularly other follow up section and other credit follow up expert. They were interested to cooperate and entertain my questions with the necessary responses.

Based on the interview conducted for interview question No.4, both respondents replied that the bank management evaluates and ensures profitability and protects its depositors against bank's lending risks by:

$>\quad$ Knowing customer (character, capacity, capital, Collateral and condition)

$>\quad$ Keeping some rate in deposit and loan

$>\quad$ Reserving money with NBE and other banks (apply in government regulation having provision for NPL)

\section{$>\quad$ Providing prudent credit \\ $>\quad$ Providing other banking services \\ $>\quad$ Assessing customer past credit history etc.}

The interviewees forward their opinion on "Do you believe the procedure followed for loan approval by the bank is satisfactory?" The required procedure is not satisfactory and their reason is it is time taking as compared to other banks since the loan is approved at the area bank and head office level. As per the interviewees Ethiopia agriculture is characterized by a subsistence level of farming. Since bank grant a loan against collateral and farmers have no valuable capital assets that can be used as collateral purpose to request loan from formal financial institutes like banks. But recently there is introduction of commercial farming like horticultural, floricultural farming, and other kinds of farming in Ethiopia.

Therefore the effect of nonperforming loan as per the interviewees has an overall effect on the bank's income decline, receivables loss and interest loss which are loses recognized by NBE.

Generally, misguiding the lending policy manual of the bank is another factor of a loan to turn sick5. Summary of Findings and Recommendation

In this chapter, a conclusion of the research findings that has been discussed and analyzed in detail in the previous chapters is briefly presented. In addition, general conclusions that are highly related with the research objective of this paper are offered. Furthermore, possible recommendations based on the findings are made.

\subsubsection{Summary of Findings}

The main concern of this study is to collect necessarily information about credit Risk management practice of the Dashen Bank S.C Mettu Branch and to seek solution for the problem that is encountered with credits granted and its recovery. In analysis the Descriptive research method is used to make the research completion. Moreover, all relevant sources of primary and secondary data were collected through interview and questionnaires. Head office of the bank was interviewed with personal interaction and questionnaires were given to employees and all staffs who have been directly involved to credits management. The following are the major findings as reported that the staff of Dashen Bank S.C Mettu Branch out of total Respondents, 93.3\% 
are a first Degree holder. However, 53.3\% of the respondents working in Bank have working experience even below than five years. $40 \%$ of the respondents believe that the processing time of granting credits approximately 8 to 14 days. $73.3 \%$ of the respondents accept the loans which is granted without any collaterals. $100 \%$ of the respondents believe that the procedures followed for loan approval by the bank are satisfactory. Out of the total respondent, $66 \%$ are agreed that there are no problem associated with implementation of policy manual of the bank as desired. Moreover, $66 \%$ of the respondents assure that the bank assess all information of borrowers related to financial history just before granting the loan and the bank usually focus on domestic trade and service sector area. Out of the total respondent $100 \%$ of them are replied that there is a credit follow up technique and procedure designed and implemented by the bank. $80 \%$ of the respondents assure that the bank have the follow up mechanism of specifically "your customers" after granting the loan. $100 \%$ of them are in opinion that the bank follows natural language processing (NLP) to automate certain document processing, analysis and customer service activities to maximize the customer's satisfactions. Out of the total respondent $56.6 \%$ are in opinion that the bank used all modern mechanism of preventing NPLs. The main cause of non-performing loan at borrower level is diversification of the borrower fund to other purpose. The main cause of non-performing loan at the bank level is lack of continuous follow up and slow-down in business or agriculture. The other major cause of non-performing loan at economic level is weak Economic plan and strategy implementation.

\subsubsection{Recommendations}

The following are some of the important recommendations derived on the basis of finding for further an improvement of Dashen Bank S.C Mettu Branch.

To increase credit quality of the Head office loan section staff members advisable gets adequate and recent training. The training advisable be based on their experience on loan processing and it advisable be in a continuous basis.

The bank advisable give more emphasize on its implementation on credit policy and procedure, in order to have a better approach that will meet the objective of the bank.

$>\quad$ The bank advisable frequently follow-up by visiting borrowers business to create long- lasting relationship and assure future payment.

In today's competitive world the bank must try to develop a sound policy in line with the existing situation of the market.

$>\quad$ The banks advisable develop different types of credit facilities to the borrower.

$>\quad$ The banks advisable assesses borrowers past financial history, credit worthiness and perform detail financial analysis before extending loans to avoid non-performing loans.

\section{Abbreviations and Acronyms}

$\mathrm{NBE}=$ National Bank of Ethiopia

$\mathrm{CRM}=$ Credit Risk Management

SPSS $=$ Statistical Package for Social Sciences

$\mathrm{KYC}=$ know Your Customer

$\mathrm{NPL}=$ Non Performing Loan

MIS= Management Information System

LRM= Loan Review Mechanism

$\mathrm{BOD}=$ Board of Director

$E L=$ Expected Loss

$\mathrm{EAD}=$ Exposure at Default

LGD $=$ Loss Given Default

SET $=$ Security Financing Transaction 
OBS $=$ Off Balance Sheet

GAAP $=$ Generally Accepted Accounting Principle

$\mathrm{VAR}=$ Value at Risk

MTM=Mark to Market

$\mathrm{DM}=$ Default Mode

$\mathrm{RCR}=$ Rural Commercial Banks

$\mathrm{SME}=$ Small and Medium Enterprises

$\mathrm{CSMI}=$ Credit Scoring Methods for Individual

S.C $=$ Share company

\section{References}

1. Abdou, H. \& Pointon, J. (2011). Credit scoring, statistical techniques and evaluation criteria: a review of the literature, Intelligent Systems in Accounting, Finance \& Management, 18(2-3), 59-88. [Google Scholar]

2. Asia S. \& Zaidi F.B. (2012). Design and Development of Credit Scoring Model for the Commercial banks of Pakistan: Forecasting Creditworthiness of Individual Borrowers, International Journal of Business and Social Science, 3. [Google Scholar]

3. Atakelt H.A. (2015). Emphatically Study on Credit Risk Management Practice of Ethiopian Commercial Banks, Journal of Finance and Accounting, 6(3), 134-147. [Google Scholar]

4. Basel Committee. (July, 1999a). Principles for the Management of Credit risk. Basel Committee on Banking Supervision. [Link]

5. Basel Committee. (September 2000). Best Practice for Credit Risk Disclosure. Committee on Banking Supervision. [Link]

6. Basel committee on banking and Supervision (2001). Sound Practice for The Management of Operational Risk. Basel committee publication No.86, Basel._[Link]

7. Bass, RMV. (1991). Credit management (3rd Ed.) New Delhi: Stanley Thrones publishers Ltd. [Link]

8. Besi, H.L., Hardikar, V.K. (1993). Practical Banking Advances. (9th Ed.) New Delhi; UBS publishers. [Link]

9. Cebenoyan, A. S., Strahan, P. E. (2004). Risk Management, Capital Structure, and Lending at Banks, Journal of Banking and Finance, 28, 19-43. [Google Scholar]

10. Colquitt J. (2007). Credit Risk Management: How to Avoid Lending Disasters and Maximize Earning, McGraw-Hill, Two Penn Plaza, New York. [Link]

11. Edward I. A. (2006). Default Recovery Rates and LGD in Credit Risk Modeling and Practice, Stern School of Business, New York, USA. [Google Scholar]

12. Girma M. (2011). Credit risk Management and Its Impact on Performance on Ethiopian Commercial Banks, Unpublished Master's Thesis Addis Ababa University. [Google Scholar]

13. Hagos M. (2010). Credit Management (A Case Study of Wegagen Bank Share Company in Tigray Region), Unpublished Master's Thesis Mekelle University. [Google Scholar]

14. Hand, D. J. \& Jacka, S. D. (1998). Statistics in Finance, Arnold Applications of Statistics, London. [CrossRef]

15. Harrison O. A. (2012). Credit Risk Management and Profitability of Selected Rural Banks in Ghana, Catholic University College of Ghana. [Google Scholar]

16. Hussein A., Ahmed E. \& John P. (2007). On the Applicability of Credit Scoring Models in Egyptian Banks, Banks and bank systems, 2(1).[Google Scholar]

17. Kargi, H.S. (2011). Credit Risk and the Performance of Nigeria Banks, Ahmadu Bello University, Zaria. [Link] 
18. Koch, W.T. (1995). Bank management (3rd Ed.) USA: The Dryden press, see Harbor Drive. [Link]

19. Kolapo, T. F., Ayeni, R. K. \& Oke, M. Ojo (2012). Credit Risk and Commercial Banks' Performance in Nigeria: a Panel Model Approach, Australian Journal of Business and Management Research, 2(2). [Link]

20. Korir, M. K. (2012). Effects of Credit Risk Management Practices on Financial Performance of Deposit Taking Microfinance Institutions in Kenya, University of Nairobi. [Link]

21. Machiraju, H.R. (2003). Modern commercial Banking New Delhi: Viakas publishing House Pvt.Ltd. [Link]

22. Margarita J., Kosta S. \& Suzana T. (2014). Application of the Scoring Model for Assessing the Credit Rating of Principals, Tem Journal, 3(1). [Link]

23. Michael, K. O. (2006). Risk Management -A Modern Perspective, Elsevier Inc, London, UK. [Link]

24. Million G., Matewos K. \& Sujata S. (2015). The Impact of Credit Risk on Profitability Performance of Commercial Banks in Ethiopia, African Journal of Business Management, 9(2), 59-66. [Link]

25. MS. Asha S. (2013). Credit Risk Management in Indian Commercial Banks, International Journal of Marketing, Financial Services \& Management Research, 2(7). [Link]

26. Nayan J. \& M. Kumaraswamy (2014). Retail Credit Risk Management in Indian Public Sector Banks, Hemagangotri University of Mysore. [Link]

27. Patil J.B. (2014). Credit Risk Management in Indian Banks, International Journal of Advance Research in Computer Science and Management Studies, 2(1), 309-313. [Link]

28. Ronald W.A. \& Karin J. (2014). The Economics of Collateral, The London School of Economics. [Link]

29. Rose, A.S., Westerfield, W.R., and Jordan D.B. (1998) Fundamentals of corporate Finance Corporate Finance (4th Ed.) USA: Division of the Mc Graw- Hill companies, Inc. St. Mary's University. [Link]

30. Rose, S.P. (1993). Commercial bank management (2nd Ed. ) Boston: Irwin Howin Hom Wood, IL. [Link]

31. Solomon G. (2013). Credit Risk Management Practice on NIB International Bank, Unpublished Master's Thesis, St. Mary University. [Link]

32. Sunitha R. \& J. K. Raju (2013). Risk Management in banking Sectoran Emperical study, Davangere University, Davangere. [Google Scholar]

33. Thomas, L. C. (2000). A survey of credit and behavioral scoring: forecasting financial risk of lending to consumers, International Journal of Forecasting, 16(2), 149-172. [Link]

34. Tony V. \& Bart B. (2009). Credit Risk Management: Basic Concepts, Financial Risk Component, Rating Analysis, Models, Economic and regulatory capital: Published in the United States by Oxford University Press Inc., New York. [Link]

35. Yang W. (2013). Credit Risk Management in Rural Commercial Banks in China, Edinburgh Napier University. [Link]

36. Yong H.K. (2003). Credit Granting: A Comparative Analysis of Classification Procedures, the Journal of Finance, 42(3). [Link] 